The "advancedness" of knowledge in pollutionsaving technological change with a qualitative application to SO2 cap and trade

David Grover

November 2012

Centre for Climate Change Economics and Policy Working Paper No. 118

Grantham Research Institute on Climate Change and the Environment Working Paper No. 100 
The Centre for Climate Change Economics and Policy (CCCEP) was established by the University of Leeds and the London School of Economics and Political Science in 2008 to advance public and private action on climate change through innovative, rigorous research. The Centre is funded by the UK Economic and Social Research Council and has five inter-linked research programmes:

1. Developing climate science and economics

2. Climate change governance for a new global deal

3. Adaptation to climate change and human development

4. Governments, markets and climate change mitigation

5. The Munich Re Programme - Evaluating the economics of climate risks and opportunities in the insurance sector

More information about the Centre for Climate Change Economics and Policy can be found at: http://www.cccep.ac.uk.

The Grantham Research Institute on Climate Change and the Environment was established by the London School of Economics and Political Science in 2008 to bring together international expertise on economics, finance, geography, the environment, international development and political economy to create a worldleading centre for policy-relevant research and training in climate change and the environment. The Institute is funded by the Grantham Foundation for the Protection of the Environment and the Global Green Growth Institute, and has five research programmes:

1. Global response strategies

2. Green growth

3. Practical aspects of climate policy

4. Adaptation and development

5. Resource security

More information about the Grantham Research Institute on Climate Change and the Environment can be found at: http://www.lse.ac.uk/grantham.

This working paper is intended to stimulate discussion within the research community and among users of research, and its content may have been submitted for publication in academic journals. It has been reviewed by at least one internal referee before publication. The views expressed in this paper represent those of the author(s) and do not necessarily represent those of the host institutions or funders. 


\title{
The 'advancedness' of knowledge in pollution-saving technological change with a qualitative application to SO2 cap and trade
}

\author{
David Grover \\ Department of Geography and Environment \\ London School of Economic and Political Science \\ Houghton Street \\ London WC2A $2 \mathrm{AE}$ \\ $\mathrm{T}:(+44) 7899691268$ \\ $\mathrm{F}:+44(0) 2079557412$ \\ E: d.grover@lse.ac.uk \\ June 2012
}




\section{Abstract}

This paper investigates the extent to which 'advanced' knowledge and technology is likely to play a role in reducing greenhouse gas (GHG) emission in future by looking at the role that advanced knowledge and technology played in the technological change process that reduced SO2 emissions under the US SO2 cap and trade program. It investigates the hypothesis that advanced knowledge and technology dedicated to pollution abatement played a minor role in that process while pre-existing, relatively unadvanced forms of knowledge and technology played the main role. New qualitative evidence is used to investigate the hypothesis including interviews with electric power plant R\&D managers, plant-level compliance data, and the nature of the changes undergone by the boiler manufacturer, coal mining and railroad companies in the plants' upstream supply chain. The paper finds that advanced knowledge dedicated to pollution abatement like the type now being emphasised for carbon capture and storage (CCS) played a minor role, while unadvanced knowledge and technology as well as general purpose knowledge repurposed to the pollution problem, played the main role. There are limits to how far these findings can be generalised to the role that knowledge will play in controlling GHG emissions. Nonetheless, one contribution is to point out that at least with respect to reducing pollution emissions, 'innovation' in pollution control can be inexpensive and effective without involving universal advance in dedicated pollution control technology. 
Key words: knowledge, technological change, air pollution, supply chain

\section{Table of contents}

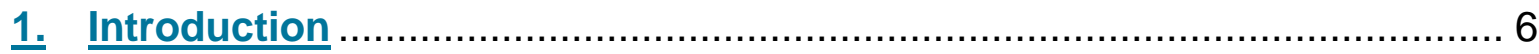

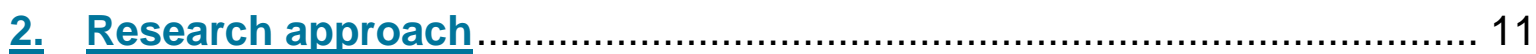

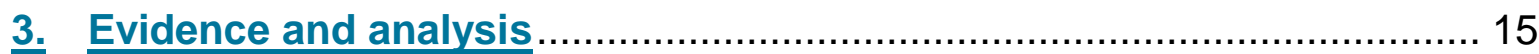

3.1. Plant-level compliance.................................................................. 15

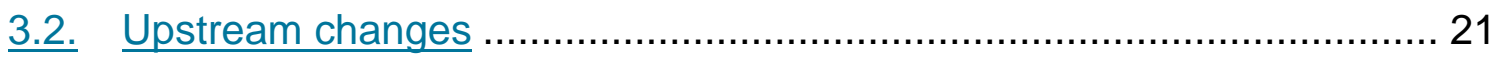

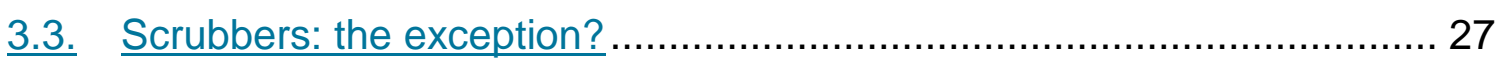

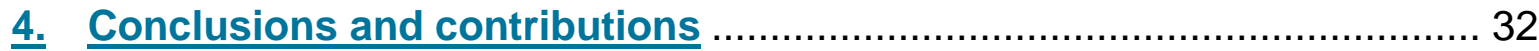

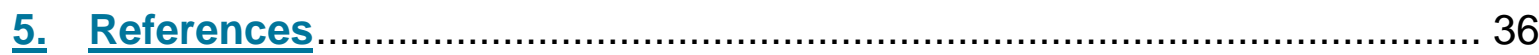




\section{Introduction}

This paper investigates the degree of 'advancedness' of the scientific and engineering (technical) knowledge that is likely to play a role in reducing greenhouse gas (GHG) emissions today and in future. It tests the hypothesis that under certain policy conditions, the most advanced forms of knowledge and technology dedicated to pollution abatement can play a relatively small role in the technological change process that reduces emissions while relatively unadvanced forms of knowledge and technology play the main role. The degree of advancedness of knowledge in this process has important implications for GHG abatement policy design and for theory.

This hypothesis is tested by examining the role of knowledge and technologies of different degrees of advancedness in the technological change undergone in the electric power sector under the US SO2 cap and trade program (the Program). Different to other studies (Kumar and Managi 2010; Färe, Grosskopf and Pasurka 2007; Popp 2002) this paper takes a qualitative approach to examining the role of knowledge and technology. It examines interview evidence from plant R\&D managers, fuel purchasing managers and environmental compliance employees at US electric power plants. It probes behind the compliance strategies of the plants themselves to the technical changes undergone in the coal mining, boiler manufacturing and railroad shipping industries. Evidence is considered for the extent of uptake of flue gas desulphurisation ('scrubbing') technology, which has some similarities in terms of advancedness with some of the technologies being developed to control GHGs, particularly carbon captures and storage (CCS). The paper 
considers in a descriptive-analytical way the role of knowledge and technology in 16,000 plant-level SO2 compliance strategy declarations reported by plant operators during the period 1996-2005.

This 'unadvanced knowledge' hypothesis is motivated by a discrepancy between the amount of emphasis placed on advanced environmental technologies for meeting GHG emission reduction targets in future and the more limited role that advanced environmental technologies seem to have played in controlling comparable pollution emissions historically. For example the Environmental Protection Agency (EPA) of the United States recently proposed a GHG emission standard that would pertain to all new and modified electric generating units in the continental United States (EPA 2012a). The proposed standard states that all new electric generating units limit their $\mathrm{CO} 2$ emissions to 1,000 pounds of $\mathrm{CO} 2$ per $\mathrm{mWh}$ of electricity produced. Electric power producers would be able to comfortably meet this standard by choosing to construct units that are fired by natural gas.

The EPA also set out an 'alternative' compliance option for producers that might wish to construct units that are fired by coal. The alternative compliance option states that producers would still meet the $1,000 \mathrm{lbs}$ CO2 per mWh standard but that they would meet it over a 30 year period on an 'averaging' basis. Producers would be permitted to meet an interim standard of $1,800 \mathrm{lbs} \mathrm{CO} 2$ per $\mathrm{mWh}$ for the first 10 years before being obliged to reduce emissions to no more than $600 \mathrm{lbs} \mathrm{CO} 2$ per $\mathrm{mWh}$ for all subsequent years (2012a: 32-33). EPA explicitly states in the proposed rule that the interim standard of $1,800 \mathrm{lbs} \mathrm{CO} 2$ per $\mathrm{mWh}$ would need to be met by supercritical or ultra supercritical coal combustion techniques. The proposed 
rule explicitly states that the subsequent 600 lbs CO2 per mWh standard would need to be met by carbon captures and storage (CCS) (EPA 2012b: 32$33,38-40,73-74,117-145)$. The proposed rule does not state that any other technology besides (ultra) supercritical coal combustion and CCS would be permitted under the alternative compliance option. This is concerning because an important lesson that emerged from environmental regulation in the 1970s was that requiring polluters to use regulator-designated technologies to reduce pollution can be economically inefficient, legally adversarial and ineffective at limiting environmental damage quickly (Davis et al. 1977; Seskin, Anderson and Reid 1983; Reitze 2001).

Also in the literature it is common to pre-supposed that technologies characterised by advanced knowledge, and technologies that arise from the universal advancement of knowledge (Furman, Porter and Stern 2002) will play the leading role in reducing future GHG emissions (Barrett 2006; Hoffert et al. 2002; Castelnuovo et al. 2005; Riahi, Rubin and Schrattenholzer 2004; Riahi 2004; Stern 2006). This expectation may not be entirely realistic given the uncertainty surrounding the extent to which advanced knowledge and technology has played a role in reducing comparable kinds of pollution emissions historically.

Levinson (2009) decomposed the causes of the decline in the pollution intensity (NOx, SOx, CO and VOC) of 450 four-digit US manufacturing sectors for the period $1987-2001$. He found that a 'technique' effect accounted for a 60 per cent fall in emissions. The technique effect was measured as the residual after controlling for scale and composition. This begs the question about the type of knowledge and technology behind this effect. Popp (2010) 
used US and foreign patent data to investigate the effect of technological progress on the adoption of post-combustion and combustion modification NOx control technology in the US. In one specification Popp found that the anti-adoption effect of foreign knowledge effectively offset the pro-adoption effect of domestic knowledge, for a net effect of technological progress of near zero (2010: 24). Popp found that knowledge played a bigger role in the adoption of post-combustion technology than in the adoption of combustion modification technology. Stern (2002) decomposed the change in sulphur emissions for 64 countries (1973 - 1990) into scale effects, inter-industry composition effects, input effects, and 'technical change' effects. He decomposed technical change effects into emission-specific ('cleaner production') and general effects ('the effects of shifts of output composition within each of the four broad industry sectors') (217). Stern found that both types of technical change exerted a strong negative effect on cross-country emission intensity. The role of knowledge in this technical change effect remains unclear. Sue Wing (2008) decomposed the aggregate change in the energy intensity of output in the US economy for the period 1958-2000. Sue Wing found that the creation of new technical knowledge and technological progress accounted for the smallest amount of this change (-8.8 per cent). Inter-sectoral structural change accounted for the most (-32.6 per cent) and changing capital stock structures accounted for -16.1 per cent.

Under the US SO2 cap and trade program specifically, advanced knowledge and technologies dedicated to pollution control seem to have played a smaller role in the emission reduction outcome than was expected at the outset of the Program. Carlson et al. (2000) investigated the extent to 
which the unexpectedly low cost of reducing SO2 under the Program could be explained by the allowance trading provision alone. Carlson et al. concluded that the combination of "technological change" and the fall in the cost of lowsulphur coal were responsible for lowering the marginal abatement cost curves faced by emitters by over 50 per cent from 1985. Carlson et al. estimate that technological 'change' accounted for about 20 per cent of these cost reductions while fuel switching accounted for 80 per cent. Ellerman et al. (1997) estimate that 45.1 per cent of the total emission reduction achieved under the Program came from installing flue gas desulphurisation (FGD) units, and that 54.9 per cent came from switching to lower sulphur fuels. Ellerman et al. were more circumspect about attributing the unexpectedly low cost of abatement to progress in pollution control-related technologies. In concluding their discussion of the causes of the unexpectedly low price of SO2 emission credits as of 1998, they wrote:

There certainly was some induced innovation. For example, the observed per-ton cost of scrubbing in 1995 was substantially below earlier estimates, and our investigation indicates that this difference reflected unanticipated improvements in instrumentation and controls that reduce personnel requirements, innovative sludge removal techniques, and higher than expected utilization of scrubbed units (which reduces capital cost per ton of sulfur removed). Moreover, new ways were found to adapt midwestern boilers to blends of local and Powder River Basin coals. Although such adaptation was underway prior to 1990, it may well have been accelerated by the passage of Title IV. However, the dramatic gap between actual and expected allowance prices is simply too large to be accounted for by the observed technological improvements [emphasis added]. (1997: 65)

Ellerman et al. (1997) observe in this passage that these relatively advanced innovations are probably not sufficient to account for the extent of

\footnotetext{
${ }^{1}$ Carlson et al. use 'technological change' interchangeably with 'technological improvements' and 'technical progress'.
} 
low-cost SO2 reductions observed under the Program. The kinds of technical changes identified here as innovative, such as improved instrumentation, improved sludge removal techniques and higher utilisation of flue gas desulphurisation (scrubber) units, are discussed in detail to follow.

This motivates a closer look at the role of knowledge and technology of different degrees of advancedness in the technological change process that reduced $\mathrm{SO} 2$ emissions. The next section discusses what is meant by the 'advancedness' of knowledge, the research approach and the data analysed. Section 3 presents and analyses the data. Section 4 concludes with the contributions of the findings.

\section{Research approach}

A 'technology' is defined here as a production possibility. It is the ability to systematically and repeatedly carry out a productive transformation of materials and energy from lower value form to higher value form in a way that yields some product or state that is useful to human beings (Metcalf 1995: 34; Romer 1994; Schumpeter 1939). The technical knowledge that a producer possesses limits its production possibility breadth. The availability of inputs, their cost and other factor bear on the extent to which the producer is able to render any given production possibility in its repertoire into practice, but they do not limit the range of production possibilities in the sense that a possibility is abstract from and separate to its application.

Some varieties of knowledge and technology are more 'advanced' than others. Advancedness can be considered as the position of a technology and 
the knowledge it embodies relative to the universal production possibility frontier (PPF) for some discrete product or outcome (Binswanger and Ruttan 1978; Nordhaus 1969; Ruttan 1959). Empirically in this paper the outcome is electricity produced from coal-fired power plants. Knowledge and technology that sit on the PPF embody the possibility of rendering a product or outcome in a way that uses the very smallest quantity of inputs to achieve the task that is known anywhere. It is knowledge and technology that is as advanced as can be. It is state-of-the-art. Knowledge and technology that sits away from the frontier is less advanced. Less advanced knowledge and technology affords the possibility of combining the same quantity of inputs to achieve an inferior outcome compared to the outcome that the knowledge and technology at the frontier could achieve, or symmetrically, of combining a larger quantity of inputs to achieve the same outcome (Sue Wing 2006).

The technological change process that led to SO2 reductions among electric power plants under the US SO2 cap and trade program involved knowledge and technology of different degrees of advancedness. In the Figure below, the event that initiated technological change with respect to SO2 emissions would be Title IV of the 1990 Clean Air Act (CAA) Amendments. Plant operators would have inventoried the knowledge and technology possibilities available to them to respond to the policy. The most advanced possibilities for producing electricity with respect to $\mathrm{SO} 2$ emissions are considered 'frontier' knowledge. Frontier knowledge and technology would have involved promising but unrefined production techniques, a scarcity of available labour for implementing the technique, and/or relatively few instances of the technique actually being used in practice. Sub-frontier 
knowledge is considered 'applied' or 'routine' knowledge. Applied and routine knowledge and technologies tend to be heavily refined, frequently in widespread use and inefficient but inexpensive. These kinds of knowledge and technology have abundant pools of relevant labour to draw on for implementation.

\section{[FIGURE 1]}

The third column depicts the physical compliance methods from which a producer might choose, and which are bounded by the production possibility range available to it. In the case of $\mathrm{SO} 2$ control the plant operator might choose to install flue gas desulphurisation (FGD) (scrubber) technology, switch to low-sulphur coal, switch to natural gas, construct new natural gas capacity, reduce utilisation of dirty plants or buy emission allowances. The production method change these techniques bring about can be measured by direction (SO2-saving) and extent (reduction in ratio of SO2 to electricity output) (Newell, Jaffe and Stavins 1999; Loschel 2002; Gillingham, Newell and Pizer 2008).

This paper investigates the role of knowledge and technology advancedness in the policy context of the SO2 cap and trade program ${ }^{2}$ for two

\footnotetext{
${ }^{2}$ The Program established a national cap on $\mathrm{SO} 2$ emissions of 8.95 million tons per year. It targeted coal-fired electric power plants to achieve approximately 85 per cent of the reduction to meet this cap (Reitze 2001: 264). The Program proceeded in two phases: Phase 1 ran from $1^{\text {st }}$ January 1995 to $31^{\text {st }}$ December 1999 and mandated the participation of only the plants with the highest-emitting generation units in the country. Operators of the dirtiest plants were required to reduce emissions from the affected units by approximately four million tons per year. Phase 2 of the Program began on $1^{\text {st }}$ January 2000. In Phase 2, Program coverage was extended to 2,300 additional generation units and to all generation units that had yet to be built. Under Phase 2, a further four to five million tons of SO2 per year were to be eliminated. For a detailed discussion of the Program's effectiveness, see Reitze (2001).
} 
reasons. First, the technical change response of the polluter depends on the design of the policy instrument created to address the pollution problem (Kemp 1997; Kemp and Pontoglio 2011; Vollebergh 2007). The Program was designed to be relatively neutral toward the kind of knowledge and technology polluters used in their compliance decisions. The policy exerted minimal bias on the change process. The policy compelled power plant operators to reduce emissions without prescribing discrete technologies or production methods. This makes it possible to observe the role of knowledge and technology in a technological change process which is specifically pollutionsaving, 'net' of the biasing effect of policy toward specific technologies (Davis et al. 1977; Seskin, Anderson and Reid 1983; Kemp 1997)

Second, technical knowledge is very difficult to observe empirically and a range of qualitative evidence is used to address this difficulty (Yin 2009). The evidence includes: generation unit-level SO2 compliance strategy data from the Energy Information Administration (EIA); nine extended interviews conducted with research managers, fuel purchasers and compliance specialists who worked on SO2 emissions issues during the 1980s and 90s; research reports from the Electric Power Research Institute (EPRI) into the economic and engineering implications of $\mathrm{SO} 2$ control legislation for US electric utilities; the original text of the Clean Air Act Amendments of 1970, 1977 and 1990; government documents; and secondary academic studies of the outcomes of the Program. Each is used to gain a 'glimpse' of an aspect of the role of knowledge.

For a discussion of the role of permits in reducing emissions, see Schmalensee et al. 1998. For a discussion of the gains attributable to permit trading see Tietenberg (1999). 


\section{Evidence and analysis}

\subsection{Plant-level compliance}

Owners and operators of the generation units affected by the Program were free to choose from all compliance strategies virtually without restriction, to meet their emission reduction obligations. The Energy Information Administration (EIA) monitored these choices by collecting data on the frequency of use of the 14 most common compliance strategies. ${ }^{3}$

Table 1 summarises the responses for all affected units over all reported years from $1996-2005 .^{4}$ The frequency column gives the total number of 'declarations' for a generation unit that it was using a particular compliance strategy in one year. Respondents had the option to state up to three compliance strategies. The table includes all strategy declarations regardless of primacy, e.g. whether a declaration was stated as the first, second or third strategy. The 'FKR' column gives an assessment of the extent to which the plant operator would have had to incorporate or acquire advanced frontier knowledge in order to implement the strategy. The assessment is the author's own based on a reading of the $\mathrm{SO} 2$ control engineering literature. Zero denotes 'zero or negligible frontier knowledge

\footnotetext{
${ }^{3}$ The form EIA-767 'Steam-electric plant operation and design' gathers information on plant characteristics, plant configuration, boiler operations and fuel use, FGD unit design characteristics and FGD unit operation. The survey instructed respondents to 'Select the existing and/or planned strategies to meet the sulphur dioxide requirements of the Title IV of the Clean Air Act Amendments of 1990'.
} 
required', one denotes 'small amount', two 'medium amount' and three 'large amount'.

\section{[TABLE 1]}

The 'FKR' column implies considerable difference across compliance strategies in the extent to which plant operators would have had to rely on frontier knowledge. The strategies that were most likely to have involved acquiring and applying frontier knowledge received the least uptake. The strategies that were least likely to have involved frontier knowledge received the least uptake. 'Repowering' a generation unit is arguably the strategy that would have stretched the plant's existing knowledge capacity furthest. 'Repowering' was defined in the 1990 CAA Amendments as:

... replacement of an existing coal-fired boiler with one of the following clean coal technologies: atmospheric or pressurised fluidized bed combustion, integrated gasification combined cycle, magnetohydrodynamics, direct and indirect coal-fired turbines, integrated gasification fuel cells... or a derivative of one or more of these technologies and any other technology capable of controlling multiple combustion emissions simultaneously with improved boiler or generation efficiency and with significantly greater waste reduction relative to the performance of technology in widespread commercial use as of the date of enactment of the Clean Air Act Amendments of 1990 (CAA 1990: 2587)

Repowering would have been one of the most frontier knowledgeintensive strategies because it involved production methods ('atmospheric or pressurised fluidized bed combustion... magnetohydrodynamics, integrated gasification fuel cells') that were not in widespread use among affected plants at the time. If a plant operator had chosen to repower an affected unit then it 
is likely that the plant would have had to: undertake considerable research into how to integrate the new unit into the existing electricity generation system; investigate the suitability of manufacturers from which to source the technology; oversee the installation of the unit; learn how to operate the unit; and maintain considerable practical on-site expertise to maintain and operate the new unit. Plant operators chose repowering as a compliance strategy in 42 out of 16,633 total declarations. That was one-quarter of one per cent of all declarations. Repowering ranked the $13^{\text {th }}$ most popular strategy out of 14 possible strategies.

The strategies that received the most widespread uptake involved preserving, extending and repurposing existing physical capital stocks. To the extent that plant operators depend on 'knowledge capital' to run the physical capital, this implies that the strategies with the most widespread uptake also preserved, extended and repurposed existing stocks of technical knowledge.

Switching to lower-sulphur fuels for example accounted for 19.27 per cent of all declarations by affected generation units. Plant operators were probably not able to switch fuels without learning anything new at all. For example switching from burning the common anthracite coal to burning the lower sulphur lignite coal for sustained periods of time tended to lead to problems with pulverisation, erosion, fouling, slagging, derating and electrostatic precipitators in the affected units (EPRI 1990). Many boilers manufactured prior to 1990 had not been engineered to burn coal with the properties of lower sulphur coals. Plant operators tended to have to alter their coal grinding equipment, update their fuel testing and handling systems, and implement measures to monitor and control what the combustion process in 
the boiler combustion chamber (EPRI 1990). Implementing these changes probably required plant operators to acquire and apply at least some new technical knowledge in order to make boilers based on older coal combustion technology run reliably on lower sulphur coal.

Two other aspects of the compliance strategy data support the idea that plant operators avoided the acquisition and application of frontier knowledge. There was almost no variation in declared compliance strategy across units within plants. It was extremely rare that a plant operator with six units under its control chose to burn lower sulphur fuel for five of its units but buy emission allowances for the sixth. At the plant level, the strategy a plant operator used for one generation unit was highly likely to be the strategy the plant operator used for all its generation units. There was also extremely little variation in declared strategy within units over time. Over the full ten year period the compliance strategy did not change once, in any year, for 85.7 per cent of all generation units affected by the Program in the entire country. There was very little evidence of generation units transitioning between compliance strategies or systematically 'evolving' from one strategy to another as might be expected from the effect of learning with time. Of the remaining 14.3 per cent of generation units that did change their strategy at some point during the ten years, the great majority changed their strategy once, from 'not decided' (ND) to 'allocated and/or purchased allowances' (WA).

The lack of variation in compliance method both within individual plants and within generation units over time is consistent with the idea that plant operators and utilities are strongly averse to new capital spending. One might infer from an aversion to new capital spending an aversion to the acquisition 
of new knowledge capital. One employee who had worked on his utility's compliance approach under the Program explained how his utility essentially used allowance-buying and fuel switching as strategies to delay new capital spending on dedicated emission control technologies (scrubbers):

In the early 1990s we were looking at ways to comply [with Title IV]... Our executives said taking a derating [reducing power output] at some of our units was an unacceptable option, so that ruled out a lot of possibilities... but we had other units that were built in the late $80 \mathrm{~s} . .$. they had big blower boxes, lots of excess mill capacity, they were fully capable of using PRB [low-sulphur Powder River Basin] coal... We eventually saw it would be possible to avoid paying a huge premium, and that we could build up a bank of allowances [by buying and burning low-sulphur coal]. Now this was Phase 1, covering 19951999. We did that at every Phase 1 unit we had. We thought we could build up 1.7 to 2 million tons of allowances so when the law got stricter we could turn in those credits and buy time until the scrubber technology was mature. You have to understand... utility guys are hugely averse to large capital spending. What our executives basically wanted was a strategy to delay capital spending while FGD matured.

This passage shows how the utility chose to exploit spare capacity and tweak already obligated capacity within its existing capital stock by switching fuels and banking allowances, rather than immediately investing in new FGD units (more capital). This should not be surprising (Carlson et al 2000; Ellerman et al 1997; EPRI 1990; Schmalensee et al. 1998). Importantly though, the centrepiece of this utility's compliance strategy was to use allowances and fuel switching to deliberately delay capital spending dedicated specifically to pollution control as far into the future as possible. To the extent that capital spending is inseparably bound together with new knowledge acquisition, this was also a tactic to delay the learning burden that would have been necessary to operate that new capital. 
Interviewees were asked about the role that $R \& D$ played in their compliance strategies and how much R\&D they performed in connection with each strategy. One R\&D manager explained how many electric utilities in the US outsource their R\&D function to the Electric Power Research Institute (EPRI) in Palo Alto, California. EPRI is an industry organisation that performs electric power research on behalf of its members. It was this respondent's view that EPRI performed the bulk of the low-grade, large-scale, routine R\&D on behalf of its membership.

EPRI is a leviathan in the industry as far as R\&D is concerned... We are different from the typical utility because we tend to be out in front of the EPRI membership. It's typical for the other large companies to have one guy in an engineering function who attends the EPRI meetings. It's almost a hobby for these owner-engineers to do R\&D. Most of them just turn the R\&D over to EPRI... We tend to let EPRI do the base-load topics. They've already sold their membership on everything they're going to do in 2010 [a year after the date of the interview]... For the topics that are highest value to us, we do them ourselves and get funding from EPRI and DOE [US Department of Energy]. If you want a military metaphor, EPRI is the heavy infantry... When we do work with EPRI on scrubber options, stuff has to be published and we typically leave the dissemination up to EPRI and other EPRI members... Sometimes we hold back the detail of our [scrubber] design work but most of the time we just don't think there's much patentable stuff there. Or there may be patentable stuff but we're not vigilant enough to find it and patent it. We're in the business of supplying electricity, not selling this scrubber equipment... Really the value for us of the R\&D is rolling up our sleeves and physically doing it. This brings us a lot of value that doesn't find its way into the final report. Our R\&D work does get out to help the industry when we have the right partners [DOE and/or EPRI], and they [the industry] will get some benefit from it, but for us we feel the trade secrets is where we get our value even though most of its published.

Here, the R\&D manager explains how EPRI as the 'heavy infantry' of the electric power industry's collective $R \& D$ function frees its members from 
having to perform the same R\&D projects themselves. EPRI captured economies of scale in the performance of electric power R\&D and particularly pollution control $R \& D$. It reduced duplicative $R \& D$ among its members. The R\&D manager also discusses the applied quality of this R\&D his utility conducted. He emphasises several times that what is valuable for his utility is the knowledge that comes from the performance of hands-on ('rolling up our sleeves') pollution control R\&D rather than from the codified, crystallised end result of $R \& D$ in the form of patentable discoveries.

\subsection{Upstream changes}

One of the most pronounced effects of the Program was to accelerate the geographic shift that was already under way in American coal mining from the high-sulphur coal deposits in the midwestern and eastern regions of the US to the low-sulphur coal deposits in the western states of Montana, Wyoming and North Dakota. Prior to cap and trade the majority of US coal production by volume had come from the midwestern and eastern Appalachian states. Western coal had been geographically distant from the major population centres of the east.

[FIGURE 2]

Figure 2 shows the geographic distribution of major coal deposits by coal rank. The midwestern and eastern states tend to be endowed with highsulphur bituminous coal. The western states tend to be endowed with sub- 
bituminous and lignite coal. Sub-bituminous and lignite coals contain significantly less sulphur by weight. The Program put a price on the sulphur content of coal. The predominately lignite coal deposit in the Powder River Basin (PRB) in the western states of Montana, Wyoming, North Dakota and South Dakota became much more valuable. Easter Appalachian coals became much less valuable (Joskow 1998). It is important to emphasise that the Program accelerated a geographic shift in coal mining activity that was already underway in the US. The Program was not the only reason for the shift.

From around 1990 the Powder River Basin region rapidly became the most important source of low-sulphur coal by volume in the country. Rapid expansion in mining activity there was marked by uptake of what might be considered advanced knowledge and technologies. Western coal deposits presented new technical challenges and opportunities for extraction because they were closer to the surface and thicker-seamed (Burtraw 2000). Eastern coal deposits by contrast tended to be thinner-seamed, deeper and more difficult to access. Eastern coal deposits also had more energy content by weight. Sufficiently thick and continuous coal seams could be harvested using a large rotating mechanical shearing device called a longwall shearer that grinds the coal away from the face of the coal seam.

[FIGURE 3]

Prior to the opening of the Powder River Basin, the typical longwall shearer in the US cut into the face of coal seams to a depth of 24 inches. 
This was typically the maximum cut depth possible given the natural features of the coal deposits in Eastern coal mines. Industrial equipment suppliers and the mining companies introduced into the Powder River Basin longwall shearers that were capable of cutting up to 37 inches in depth, and at the very largest mines, up to 42 inches in depth (Flynn 2002).

Coal cut away from the seam face underground needed to be transported to the surface to be processed, loaded and shipped. Larger, more powerful conveyer motors were installed on PRB mine sites to move the harvested coal to the surface than had previously been in widespread use in eastern mines. The width of coal-moving conveyor belts increased from 48 inches to 60 inches. To move coal from the mine mouth to rail or truck shipping points, mining companies introduced trucks with the capacity to haul 240 tons in a single payload. At the very largest mines they introduced trucks capable of hauling 320 tons in a single payload. Trucks of this scale had not been widely feasible at eastern mines due to the nature of the terrain and the scale of operations (Flynn 2002; Darmstadter 1997).

Information and communication technologies were introduced at PRB coal mining operations to improve the efficiency with which mining machinery was used and to eliminate waste and redundancy in vehicle movements. Disruption to production from broken down mining equipment was confronted with electronic sensor-enabled systems of preventative maintenance. Computer-supported automation and robotics were introduced to perform difficult or dangerous underground mining tasks, or to handle tasks requiring a high degree of precision (Darmstadter 1997; Swift 2001). Long-wall shearers became more automated. Satellite tracking of material handling equipment 
was employed at the surface to monitor transport movements, to predict production bottlenecks, and to increase equipment utilisation factors (Flynn 2002). The integration of general purpose and particularly ICT-based technologies into Western coal mining operations improved financial returns to existing physical capital investments.

Table 1 showed that lower sulphur fuels accounted for about 19 per cent of the compliance strategy declarations by the operators of plants affected by the Program. One employee at an electric utility who worked in environmental compliance at the time his utility was devising its compliance strategy discussed how the geographic, technological, regulatory and productivity change factors in the upstream supplier industries came together in what presented itself as a very low-cost compliance strategy for his employer:

Low-sulphur coal burn was fairly minor for us in the pre-1990 era... Up until the mid-90s the common coal for most of our [utility] system was West Virginia or Illinois 2.5 [per cent sulphur content coal]. Our response was a wholesale fuel switch to low-sulphur coal. We found low-sulphur fuel was available with very little premium. We had to buy our way out of some long term highsulphur contracts we'd signed, but it was worth it. Essentially the coal materialised from the Powder River Basin. The first thing we did was switch two of our largest generating sites. Today [2009] a third of the entire utility's tonnage is PRB coal. That switch had tremendous fuel price benefits as well as being low-sulphur coal. PRB coal was very close to the surface. It turned out you could mine it a lot easier [than Appalachian coal] because the terrain is flat out there and you can use huge machinery. So the mining companies could invest in capital equipment and the manpower needed to run it was very low, maybe 10 per cent compared to the East's deep mines with smaller, thinner seams. But let's go back to the late 90s. For coal here [a Southern US state] that was deep-mined we were paying 65 dollars a ton. The at-themine-price in Wyoming was 5 dollars a ton. These are the late $90 \mathrm{~s}$. Then it cost another 25 dollars to ship it all the way to Alabama and Georgia. Per ton 
is a bad way compare but it's [PRB coal] not quite half the price on an energy basis.

This passage shows how some plant operators were surprised by the attractiveness of switching to low-sulphur western coal made possible in part by upstream supply chain changes ('We had to buy our way out of some long term contracts... it turned out you could mine [PRB coal] a lot easier because the terrain is flat out there...'). At the outset of the Program plant operators expected that low-sulphur coal would be part of the answer, but they did not anticipate the extent to which the geographic shift, automation and mechanisation, and rail network investment factors would converge to push down the low-sulphur coal price to the extent that these factors did.

Railroad companies invested heavily to serve high-volume, highfrequency coal shipments leaving the PRB for eastern electric power plants. This investment was enabled by the contemporaneous deregulation of the US railroad industry, which had been underway at least since 1976 (Heller and Kaplan 1996; Swift 2001). The companies that emerged from a wave of consolidation invested hundreds of millions of dollars on coal-related expansion in the mid-1990s. The company Union-Pacific (UP) spent 187 million dollars on 'coal corridor' projects alone in 1999, which was about half of the company's facility budget (Heller and Kaplan 1996). UP also built a heavily-computerised 'National Operations Center' in Fort Worth, Texas to improve the efficiency of the freight displaces from PRB and elsewhere and to coordinate freight traffic across its network. Several rail companies purchased new high-horse-power locomotives to haul coal trains of 100 cars or more in length across the country. More powerful locomotives raised the maximum 
number of cars possible for cross-country movements and sped up arrival times. The railroad double-tracked rail lines that had been only singletracked, and triple-tracked rail lines that had only been double-tracked. This investment pushed down the delivered price of low-sulphur coal (Heller and Kaplan 1996; Swift 2001).

Several of the railroad companies entered the PRB region with very large capital investments and zero initial market share. The companies bid aggressively for new coal haulage business from the utilities. Here, a fuel purchasing manager describes the treatment he received from the companies as they tried to win a new low-sulphur coal supply contract with his utility:

As PRB started to develop, Burlington Northern [BN] and Union Pacific [UP] saw these rail routes were going to become huge business... you got cut throat competition between BN and UP. I've never been treated like a king before. I was working with the environmental compliance guys at the time. The western rail companies would fly us out to the Powder River Basin, give us a tour of the mines, they fed us on the trains, they brought in special cars to rail us from Gillette [Wyoming] to Montana. They made a big presentation about the capital investments they were planning to triple track their lines. We had salesmen all over us. Just a few of our plants alone, that would have been 24 million tons of brand new business a year for these guys. They were practically crucifying themselves cutting their prices. There was just cut throat competition between these two big western railroads... Initially they didn't even have enough cars to get [the coal] out of there. Eventually they started shipping it in 110-car-long trains. These things were so long... they would never stop moving. The cars would just run underneath the coal silos moving at 1 mile an hour and the ladies would sit up in the towers filling up the cars with the computer joysticks, then the train heads off 1,800 miles toward the east. You can imagine the volume of coal. They were triple tracking east and west and trying to figure out who was going to build more cars.

This passage shows how acute the competition became between railroad companies to sign coal transport contracts with the utilities ('... you 
got cut throat competition .... They were practically crucifying themselves cutting their prices .... You can imagine the volume of coal'). This competition was the combined effect of deregulation and Title IV. Like the coal mining companies, the railroad companies made deep changes to their geography of production and distribution. They invested in new forms of physical capital that expanded production in relatively clean directions. They scaled up aspects of their existing operations (triple tracking, high-horse-power locomotives, the computerisation of transport logistic functions). They also integrated general purpose technologies ('filling up the cars with computer joysticks') to increase production scale and eliminate waste and inefficiency.

So far the evidence suggests that frontier knowledge did not play a major role in the plant-level technical response to the Program. Routine and applied forms of knowledge and technology such as fuel-switching, permitbuying and boiler modification played a more significant role. The knowledge underlying these strategies seems to have been re-purposed and adapted to the SO2 control problem. There was a generalised resistance among plants to acquiring and applying frontier knowledge. However there is evidence of frontier knowledge and technology playing a larger role in the supplier industries that provided fuel, boilers and transportation services to the plants. The knowledge and technology made use of in the supply chain tended to be general purpose, not dedicated specifically to pollution control.

\subsection{Scrubbers: the exception?}


A major inconsistency in the generalised resistance to acquiring and applying pollution-saving frontier knowledge is flue gas desulphurisation (FGD) technology. Scrubbing is both capital-intensive and dedicated solely to pollution control. This raises questions about why scrubbers were the most widely used SO2 control technology for the two decades prior to 1990 and why some plants chose to install scrubber units even after 1990 (Taylor 2001).

Flue gas desulphurisation emerged in the early 1970 s out of a rancorous and divisive process of political and social compromise. When Federal legislation first placed limits on stationary source SO2 emissions in the early 1970s, Federal regulators were unwilling to leave the choice of compliance method to electric utilities. This was because regulators feared that a widespread switch to low-sulphur coal would trigger heavy distributional consequences for the states that mined and burned large amounts of high sulphur coal (Joskow 1998). Scrubber technology avoided disrupting established geographic patterns of economic activity by protecting mining jobs in states with companies that held long term supply contracts with electric utilities. Scrubber technology can be seen as a method of avoiding the distributional consequences from the political process of cleaning up the nation's air quality. Scrubbers helped convert states with a vested interest in coal mining away from their position as opponents to SO2 emission reduction goals (Joskow 1998; Reitze 2001).

Beginning in the early 1970s the US Environmental Protection Agency almost singlehandedly forged the technology development pathway for scrubber technology against very considerable technical, economic and political resistance. EPA spent hundreds of millions of dollars on laboratory 
R\&D, field experimentation, demonstration projects, collaboration with utilities, capacity building and knowledge dissemination to bring scrubbing technology into the mainstream. This except comes from a publication of the Air Pollution Prevention and Control Division (APPCD) of EPA's Office of Research and Development. The document is dated 1995. It documents the Agency's accomplishments developing scrubber systems during the 1970s and 1980s:

The workhorses of these [flue gas desulphurisation] control technologies, wet lime and limestone systems, better known as 'scrubbers,' have been, to a great extent, pioneered, developed, and demonstrated by EPA's Air Pollution Prevention and Control Division (APPCD)... Over a 20-year period, APPCD has established FGD as a commercially accepted technology, through dissemination of program results at regularly sponsored symposia, sponsoring a number of commercial-scale demonstrations, publishing numerous journal articles, and holding industry seminars at the conclusion of successful demonstrations to ensure that vendors are able to offer FGD innovations, commercially... To foster the development and implementation of cost-effective SO2 control technology, APPCD has:

- Conducted 15+ years of pilot wet lime and limestone FGD tests at RTP [EPA's facility at Research Park Triangle] and TVA [Tennessee Valley Authority] to improve the technology to a universal acceptance.

- Sponsored a number of commercial demonstrations to show high reliability, 90 per cent $\mathrm{SO} 2$ control wet FGD operation.

- Sponsored laboratory and field evaluation studies of power plant and FGD waste disposal

- Sponsored SO2 control technology symposia on a regular basis since 1971; conducted industry briefings to transfer successful technology demonstrations to the private sector.

- Published over 100 reports and hundreds of journal articles on FGD performance and economics.

- Published an economic model for evaluation of alternative SO2, NOx, and PM control technologies.

- Received 11 patents in SO2 control technology with several more pending. 
- During the 1970 s and early 1980 s, provided leadership through international forums such as NATO - Critical Challenges to Modern Society (NATO_CCMS) to transfer FGD technology to Europe (US EPA 1995: 1-3).

This passage supports the idea that scrubbing was a technology that emerged in part from the powerful backing of government actors committed to protecting economically vulnerable sections of society from the distributional consequences of environmental policy. In one sense, these eight bullet points describe a major success in innovation for environmental protection. Without scrubber technology it is plausible that $\mathrm{SO} 2$ control policy would have been politically unfeasible. In another sense these bullets demonstrate how far from the market-led industrial technical change pathway it was necessary to track in order to avoid economic disruption and political gridlock. EPA's leadership established scrubbers as a viable control technology. The relatively rigid regulatory regimes put in place by the 1970 and 1977 CAA Amendments essentially required that plant operators choose scrubbing as the method of control SO2 emissions (Reitze 2001).

If this interpretation is valid then plant operators should have made much less use of scrubber technology under regulatory conditions where plant operators were left to choose whichever compliance strategy they wished.

Recall that Table 1 showed that the compliance strategy of installing scrubber capacity accounted for less than two per cent of all compliance strategy declarations for plants affected by the Program. Many of the plant operators that chose to install scrubber technology under the Program came to regret their decision when the extent of the fall in the delivered price of lowsulphur coal became apparent (Schmalensee et al. 1998). These plant 
operators had underestimated the response of the upstream supplier industries. When the fall in the delivered price of low-sulphur coal became apparent, the decision to scrub looked very expensive. Further factors besides biased the technology choice of some plant operators toward scrubbers. There were rules built into the Program favouring scrubbing for example. These rules authorised EPA to award free allowances from a reserve pool of 'bonus' allowances to operators who chose to install a 'qualifying phase 1 technology' which was essentially a scrubber (CAA 1990; also see the relevant footnote under Table 1).

Secondary evidence suggests that scrubber technology did not make appreciable technological progress in the post-1990 regulatory environment. Using data on the design, performance and cost of scrubber units installed at plants in the US before and after 1990, Bellas (1998) found no significant technological progress had occurred in the technology. In a follow up study, Lange and Bellas (2005) found that scrubbers installed under Title IV were cheaper to purchase and operate than older scrubbers, but that the cost reductions were a one-off drop rather than a continual decline. Taylor et al. (2005) found that scrubber technology improved in terms of cost and performance, but that the improvements occurred before Title IV came into force in 1995, in the anticipation years. This is consistent with the idea that scrubber manufacturers accustomed to a technology forcing regime prior to 1990 misjudged the response to the new market-based design of Title IV. Keohane (2007) found that the installed cost of a unit of scrubber capacity remained nearly constant throughout the period 1995 - 2000. This secondary evidence does not suggest that the post-1990 regulatory regime created 
strong incentives favouring the further development and uptake of scrubber technology. This is consistent with the pattern of plant operators resisting frontier knowledge-intensive compliance strategies in favour of strategies that involved adapting and repurposing the routine and applied knowledge were already using proficiently.

This evidence suggests that scrubbing technology benefitted from heavy government promotion in the two decades prior to 1990 . This promotion was right and justified. Promotion was necessary to avoid the distributional consequences across US states of enacting environmental policy in that era. This promotion took the form of extensive technology supports on the supply side, and rigid scrubber-forcing regulation on the demand side. These forces effectively steered the course of technological change away from the path that market forces would have compelled it to follow if distributional concerns had not been an issue.

\section{Conclusions and contributions}

This paper investigated the hypothesis that under certain regulatory conditions advanced knowledge and technologies dedicated to pollution abatement can play a minor role in pollution-saving technological change while routine and applied forms of knowledge and technology, adapted to the task of pollution control where necessary, can play a large role.

Under SO2 cap and trade at the level of the electric power plant, plant operators tended to avoid compliance strategies that involved acquiring and 
applying frontier technical knowledge dedicated solely to controlling SO2 emissions. They favoured pragmatic, low-cost, low-learning technical adjustments that preserved existing physical capital stocks and which adapted existing production methods to new restrictions. The deepest changes overall did not occur at the level of the plant but among the companies that provided fuel, boiler equipment and transportation services to the plants. These supply chain changes occurred in locations that were geographically distant to the plants themselves. They occurred in stereotypically 'dirty' industries. They occurred in unexpected technology areas like coal mining, combustion technology and railroad network signalling. Dedicated pollution-control technology received very little uptake under the Program. The extent of lowcost abatement made possible by these supply chain changes was to a large extent not foreseen (Ellerman et al ; Burtraw 2000; Burtraw and Palmer 2003; Carlson et al 2000; Ellerman et al 1997)

An important caveat to these findings is the relatively short time frame of the study period. The plant-level analysis only covered the years 19962005 and while it may be reasonable to conclude that advanced knowledge and technology did not play the driving role in reducing $\mathrm{SO} 2$ emissions under the Program, there are probably limits to the extent to which this finding can be generalised to the far future. If regulators continue to tighten the $\mathrm{SO} 2$ emissions cap in the US, driving up the cost of emission permits, this could justify investment by plant operators in frontier knowledge-rich compliance strategies. The economics of scrubbing, and of acquiring the technical knowledge of learning how to scrub, could become more attractive. A higher 
compliance cost could also trigger more frontier knowledge-intensive innovations in the supply chain.

There are also limits to the extent to which the 'unadvanced knowledge' hypothesis can be generalised to the problem of controlling GHG emissions. SO2 and GHG pollution have commonalities (Perkins and Neumayer 2008) but there are also important differences. There may be fewer known techniques for reducing GHG emissions separately from reducing electricity production altogether. There may be fewer options for stripping GHG pollution out of the supply chain. Deep GHG cuts of 80 percent or more may eventually raise the cost of abatement to a level that justifies substantial investment in advanced pollution control technologies like CCS. GHG abatement strategies involving routine and applied knowledge and technology may be heavily used in the short and medium term before giving way to more advanced approaches in the longer term.

Nonetheless this investigation of the degree of advancedness of the technical knowledge involved in pollution-saving technological change makes several contributions to the literature concerned with technological change and policy design for controlling GHG emissions. One is to highlight the extent of the supply chain changes that can occur in response to an emission constraint when policymakers to do not prescribe specific abatement approaches to polluters. The supply chain changes in this study occurred in old, heavy, stereotypically dirty industries but they were inexpensive and effective. This complements prior studies that have considered the effect of innovation and technological progress on emission outcomes at plant level (Bellas 1998; Carlson et al. 2000; Ellerman et al. 1997; Lange and Bellas 
2005; Popp 2010; Yaisawarng and Klein 1994). It gives a more rounded understanding of the decentralised, unpredictable, sometimes frontier knowledge- and learning-unintensive change process that can occur in response to a pollution constraint.

The generalised resistance to acquiring and applying frontier knowledge and especially that related to pollution abatement also helps explain why some compliance strategies are more widely adopted than others. Low cost abatement opportunities distinguish themselves from high cost abatement opportunities in part by being more plentiful and more accessible (Hanley, Shrogen and White 2006). These findings imply that low cost abatement opportunities are more plentiful and accessible in part because they do not involve the uncertainty of acquiring and applying frontier knowledge that may be tenuous and uncertain. The learning burden embedded in the different abatement opportunities is itself a reason why these opportunities locate in different places along the abatement cost curve. Opportunities for low cost GHG abatement are likely to involve low amounts of learning and frontier knowledge application.

In light of the policy design questions surrounding GHG emission regulation in the US and elsewhere, these findings bring empirical evidence to bear on nature of the innovation induced by market-based instruments (Jaffe, Newell and Stavins 2000; Hahn and Stavins 1992; Kemp and Pontoglio 2011; Newell and Stavins 2003; Vollebergh 2007). This investigation does not find that SO2 cap and trade strongly rewarded the creation or application of frontier technical knowledge at least in the medium term. Instead the Program gave firms the freedom to dismiss frontier knowledge-intensive strategies in 
favour of well-known, well-tested, inexpensive techniques that did not involve a large technical learning burden. This implies that at least with respect to pollution control, innovation under these kinds of instruments need not be synonymous with technological advance.

\section{References}

American Coal Foundation (2005) 'Coal Mining States' http://www.ket.org/trips/coal/agsmm/agsmmwhere.html.Accessed March $8^{\text {th }}$, 2011.

Barrett, S (2006) 'Climate Treaties and Breakthrough Technologies', American Economic Review 96 (2) 22-25.

Bellas, AS (1998) 'Empirical evidence of advances in scrubber technology', Resource and Energy Economics 20: 327-343.

Binswanger, H and V Ruttan (1978) Induced Innovation: Technology, Institutions and

Development Baltimore: Johns Hopkins Press.

Burtraw, D., 2000. Innovation under the Tradable Sulfur Dioxide Emissions Permits 
Program in the US Electricity Sector. Discussion Paper No. 00-38. Resource for

Future, Washington DC.

Burtraw, D and K Palmer (2003) 'The Paparazzi Take a Look at a Living Legend: The SO2 Cap-and-Trade Program for Power Plants in the United States,' Resources for the Future Discussion Paper 03-15. Washington, D.C.

Carlson, C, D Burtraw, M Cropper and K Palmer (2000) 'Sulphur Dioxide Control by Electric Utilities: What Are The Gains From Trade?', Journal of Political Economy 108 (61): 1292-1325.

Carter, R (1996) 'PRB Production to Reach 360 Million Tons by 2005', Coal August: 31-35.

Castelnuovo, E, M Galeotti, G Gambarelli, S Vergalli (2005) 'Learning-byDoing vs. Learning by Researching in a model of climate change policy analysis,' Ecological Economics 54 (2-3): 261-276.

Darmstadter, J (1997) 'Productivity Change in US Coal Mining', Resources for the Future Discussion Paper 97-40 (with Brian Kopp). Washington, DC.

Davis, CP, JR Kurtock, JP Leape and FC Magill (1977) 'The Clean Air Act Amendments of 1977: Away From Technology Forcing?', Harvard Environmental Law Review 2 (1): 1-102. 
Ellerman, AD, R Schmalensee, P Joskow, J Montero and E Bailey (1997) ‘Emissions trading

under the U.S. acid rain program: evaluation of the compliance costs and allowance market performance', Cambridge, MA: MIT Center for Energy and Environmental Policy Research.

Electric Power Research Institute (1990) Clean Air Response: A Guidebook to Strategies. Prepared by Temple, Barker and Sloane Inc. Palo Alto, California.

Färe, R, S Grosskopf and CA Pasurka (2007) 'Pollution abatement activities and traditional productivity', Ecological Economics 62: 673-682.

Flynn (2002) 'Impact of Technological Change and Productivity on the Coal Market.' Washington, DC: Energy Information Administration Issues in Midterm Analysis and Forecasting.

Furman, JL, ME Porter and S Stern (2002) 'The determinants of national innovative capacity', Research Policy 31: 899-933.

Gillingham, K., RG Newell and WA Pizer (2008). 'Modelling endogenous technological change for climate policy analysis', Energy Economics 30 (6): 2734-2753. 
Griliches, Z (1990) 'Patent statistics as economic indicators: A survey, Part I.' NBER working paper 3301. Cambridge, MA.

Hahn, RW and RN Stavins (1992) 'Economic Incentives for Environmental Protection: Integrating Theory and Practice', American Economic Review 82: 464-468.

Heller, J and S Kaplan (1996) 'Coal Supply and Transportation Markets During Phase One: Change, Risk and Opportunity.' Report prepared for the Electric Power Research Institute, January. Palo Alto, California: EPRI.

Hanley, N, J Shrogen and B White (2006) Environmental economics in theory and practice. New York: Palgrave Macmillan.

Hoffert, MI, K Caldeira, G Benford, DR Criswell, C Green, H Herzog, AK Jain, HS Kheshgi, KS Lackner, JS Lewis, HD Lightfoot, W Manheimer, JC Mankins, ME Mauel, ME Schlesinger, T Volk and TML Wigley (2002) 'Advanced Technology Paths to Global Climate Stability: Energy for a Greenhouse Planet', Science 298 (5595): 981-987.

Jaffe, AB, RG Newell and RN Stavins (2003) 'Technological change and the environment.' Chapter 11 in Handbook of Environmental Economics, Volume 1, edited by KG Maler and JR Vincent. Amsterdam: Elsevier Science, pp. 461-516. 
Joskow, PL (1998) 'The Political Economy of Market-Based Environmental Policy: The US Acid Rain Program', Journal of Law and Economics 41: 3784.

Joskow, PL, R Schmalensee and EM Bailey (1998).'The Market for Sulfur Dioxide Emissions', American Economic Review 88 (4) 669-685.

Kemp, R (1997) Environmental Policy and Technical Change: A Comparison of the Technological Impact of Policy Instruments. Cheltenham: Edward Elgar.

Kemp, R and S Pontoglio (2011) 'The innovation effects of environmental policy instruments - a typical case of the blind man and the elephant', Ecological Economics 72:

28-36.

Keohane, NO (2007) 'Cost savings from allowance trading in the 1990 Clean Air Act: Estimates from a choice-based model', in Charles E. Kolstad and Jody Freeman, eds., Moving to Markets in Environmental Regulation: Lessons from Twenty Years of Experience. New York: OUP.

Kumar, S and S Managi (2010) 'Sulfur dioxide allowances: Trading and technological progress', Ecological Economics 69: 623-631. 
Lange, I and A Bellas (2005) 'Technological Change for Sulfur Dioxide Scrubbers under Market-Based Regulation', Land Economics 81 (4) 546-556.

Levinson, A (2009) 'Technology, international trade and pollution from US manufacturing', American Economic Review 99 (5) 2177-2192.

Metcalf, JS (1995) 'Technology systems and technology policy in an evolutionary framework', Cambridge Journal of Economics 19: 25-46.

Newell, RG, AB Jaffe and RN Stavins (1999) 'The induced innovation hypothesis and energy-saving technological change', Quarterly Journal of Economics 114: 941-975.

Nordhaus, WD (1969) Invention, Growth and Welfare: A Theoretical

$\underline{\text { Treatment of }}$

Technological Change. Cambridge, MA: MIT Press.

Perkins, R and E Neumayer (2008) 'Fostering environment-efficiency through transnational linkages? Trajectories of CO2 and SO2, 1980-2000', Environment and Planning A 40 (12): 2970-2989.

Popp, D (2002) 'Pollution Control Innovations and the 1990 Clean Air Act', Journal of Policy Analysis and Management 22 (4): 641-660. 
Popp, D (2010) ‘Exploring Links Between Innovation and Diffusion: Adoption of NOx Control Technologies at US Coal-fired Power Plants', Environmental and Resource Economics 45 (3): 319-352.

Reitze, AW (2001) Air pollution control law: compliance and enforcement.

Washington, D.C.: Environmental Law Institute.

Riahi, K, ES Rubin and L Schrattenholzer (2004) 'Prospects for carbon capture and sequestration technologies assuming their technological learning', Energy 29 (9-10): 1309-1318.

Riahi, K, ES Rubin, MR Taylor, L Schrattenholzer and D Hounshell (2004) 'Technological learning for carbon capture and sequestration technologies', Energy Economics 26: 539-564.

Romer, P (1994) 'The Origins of Endogenous Growth', Journal of Economic Perspectives

8 (1): 3-22.

Ruttan, VW (1959) 'Usher and Schumpeter on Invention, Innovation, and Technological

Change', Quarterly Journal of Economics 73: 596-606. 
Schmalensee, R, PL Joskow, AD Ellerman, TP Montero, EM Bailey (1998) 'An interim evaluation of sulfur dioxide emissions trading', The Journal of Economic Perspectives 12 (3): 53-68.

Schumpeter, JA (1939) Business Cycles, Volumes I and II. New York: McGraw-Hill.

Seskin, EP, RJ Anderson and RO Reid (1983) 'An empirical analysis of economic strategies for controlling air pollution', Journal of Environmental Economics and Management 10 (2) 112-124.

Stern, D (2002) 'Explaining changes in global sulphur emissions: an econometric decomposition approach', Ecological Economics 42 (1-2): 201220.

Stern (2006) 'Stern Review on the Economics of Climate Change (prepublication edition) Executive Summary.' London: HM Treasury.

Sue Wing, I (2006) 'Representing induced technological change in models for climate policy analysis', Energy Economics 28: 539-562.

Sue Wing, I (2008) 'Explaining the declining energy intensity of the US economy', Resource and Energy Economics 20: 21-49. 
Swift, B (2001). 'How Environmental Laws Work: An Analysis of the Utility Sector's Response to Regulation of Nitrogen Oxides and Sulfur Dioxide Under the Clean Air Act', Tulane Environmental Law Journal 14 (1) 309-426.

Taylor, M (2001) 'The Influence of Government Actions on Innovative Activities in the Development of Environmental Technologies to Control Sulfur Dioxide Emissions from Stationary Sources.' PhD thesis, Carnegie Mellon University.

Taylor, MR, ES Rubin and DA Hounshell (2005) 'Control of SO2 emissions from power plants: A case of induced technological innovation in the US', Technological Forecasting \& Social Change 72: 697-718.

US Energy Information Administration (1997) 'Coal Industry Annual 1997,' DOE/EIA-0548(97), Table 1. Washington, DC: EIA.

US Environmental Protection Agency (1995) 'Flue Gas Desulfurization Technologies for Control of Sulfur Oxides: Research, Development and Demonstration', Office of Research and Development, Washington, DC.

US Environmental Protection Agency (2012a) 'Standards of Performance for Greenhouse Gas Emissions for New Stationary Sources', Proposed rule, 40 CFR Part 60. Docket no. EPA-HQ-OAR-2011-0660. 
US Environmental Protection Agency (2012b) ‘Regulatory Impact Analysis for the Proposed Standards of Performance for Greenhouse Gas Emissions for New Stationary Sources: Electric Utility Generating Units', Office of Air Quality Planning and Standards. EPA-452/R-12-001. Research Triangle Park, NC.

US Congress (1990) 'An Act to amend the Clean Air Act to provide for attainment and maintenance of health, protect national ambient air quality standards, and other purposes.' Public law No. 101-549: 104 Stat 2399-2712.

Vollebergh, H (2007) 'Impacts of Environmental Policy Instruments on Technological Change.' Report for Joint Meetings of Tax and Environment Experts. OECD Environment Directorate Working Paper COM/ENV/EPOC/CTPA/CFA(2006)36/FINAL. Paris: OECD.

Yaisawarng, S and JD Klein (1994) 'The Effects of Sulfur Dioxide Controls on Productivity Change in the U.S. Electric Power Industry', The Review of Economics and Statistics 76 (3): 447-460.

Yin, RK (2009) Case study research: Design and methods. Los Angeles: Sage. 
TABLES AND FIGURES 
Figure 1-1: Knowledge of different degrees of advancedness in a process of pollution-saving technological change

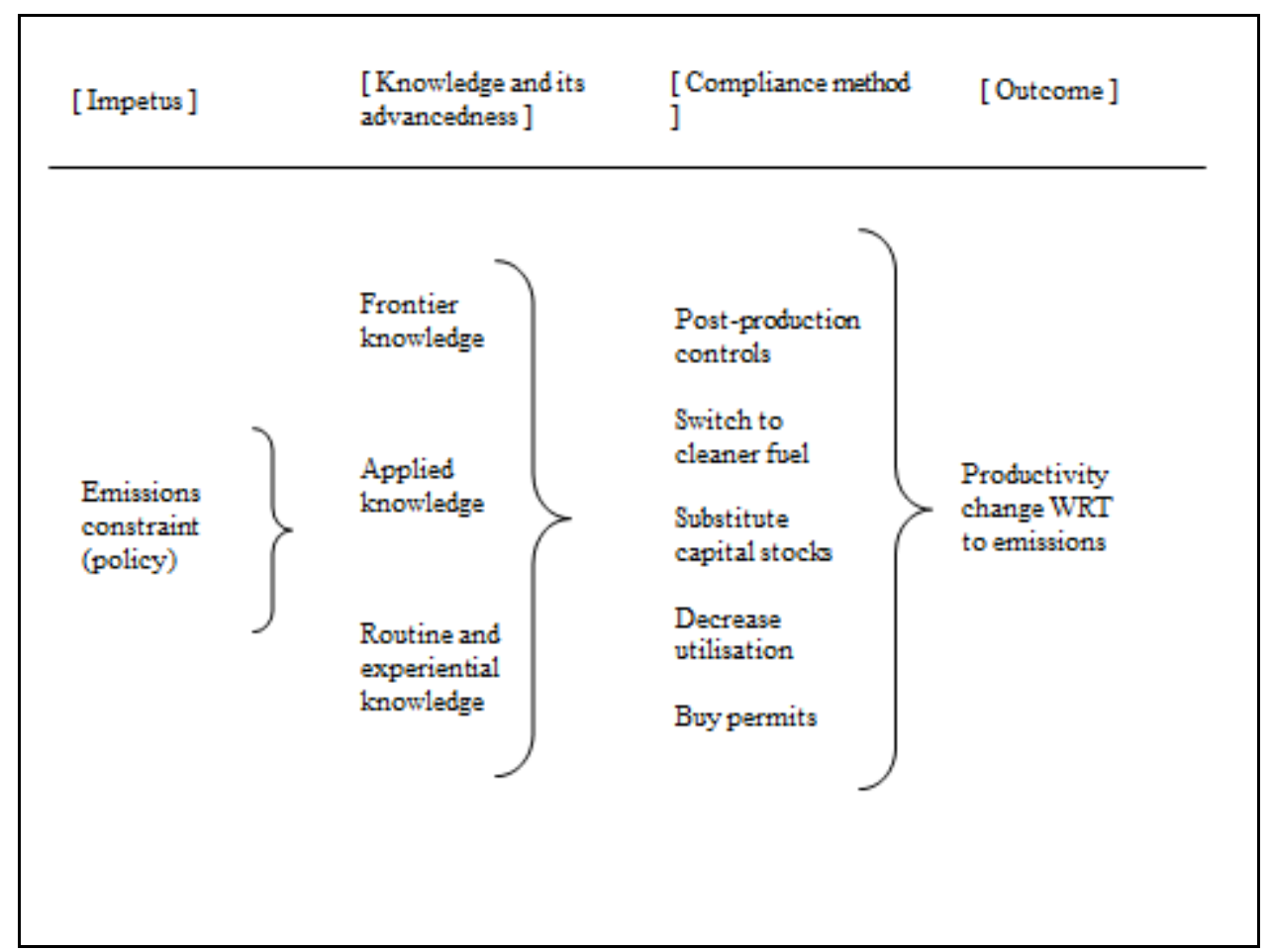


Table 1: Unit level compliance strategies with Title IV, 1996 - 2005

\begin{tabular}{|c|c|c|c|c|}
\hline & Label & Freq & Perc & FKR \\
\hline $\begin{array}{l}\text { Allocated allowances and/or purchase } \\
\text { allowances }\end{array}$ & WA & 7129 & 42.86 & $0-1$ \\
\hline No change in historic operation of unit & $\mathrm{NC}$ & 3812 & 22.92 & 0 \\
\hline Switch to lower sulphur fuel & SS & 3206 & 19.27 & $1-2$ \\
\hline Not determined at this time & ND & 488 & 2.93 & 0 \\
\hline $\begin{array}{l}\text { Designate Phase II unit(s) as substitution } \\
\text { unit(s) }\end{array}$ & SU & 474 & 2.85 & 1 \\
\hline Other & OT & 330 & 1.98 & - \\
\hline $\begin{array}{l}\text { Decrease utilisation - designate sulphur- } \\
\text { free generator(s) to compensate }\end{array}$ & US & 308 & 1.85 & 1 \\
\hline Transfer unit under Phase I extension plan ${ }^{6}$ & TU & 304 & 1.83 & $0-1$ \\
\hline $\begin{array}{l}\text { Install FGD unit (other than under Phase I } \\
\text { extension plan) }\end{array}$ & IF & 294 & 1.77 & 3 \\
\hline Control unit under Phase I extension plan ${ }^{7}$ & $\mathrm{CU}$ & 119 & 0.72 & 2 \\
\hline
\end{tabular}

${ }^{5}$ This involved shifting the unit's emission reduction obligation to a different unit under the operator's control. The emission reduction requirement could be reassigned to a unit with a lower compliance cost for example (CAAA 1990: 2593 - 2594).

${ }^{6}$ Same as 'designate Phase II unit(s) as substitution unit(s)', except instead of controlling unit emissions directly using a 'qualifying' technology the operator transferred the emission reduction obligation to a unit employing a qualifying technology.

${ }^{7}$ Under a Phase 1 extension plan a plant operator was allowed to extend the compliance deadline for a unit by up to two years provided that the operator held valid allowances for all emissions from the unit during the two years and that the operator either employed a 'qualifying Phase 1 technology' or transferred the emission reduction obligation for the unit to a unit employing a qualifying Phase 1 technology. A qualifying Phase 1 technology is 'a technological system of continuous emission reduction which achieves a 90 per cent reduction in emissions of sulphur dioxide from the emissions that would have resulted from the use of fuels which were not subject to treatment prior to combustion' (CAAA 1990: 2588). 


\begin{tabular}{|c|c|c|c|c|}
\hline $\begin{array}{l}\text { Decrease utilisation - rely on energy } \\
\text { conservation and/or improved unit } \\
\text { efficiency }^{8}\end{array}$ & UE & 56 & 0.34 & 2 \\
\hline Decrease utilisation - purchase power & UP & 43 & 0.26 & 0 \\
\hline Repower unit $^{9}$ & $\mathrm{RP}$ & 42 & 0.25 & 3 \\
\hline $\begin{array}{l}\text { Decrease utilisation - designate Phase II } \\
\text { units as compensating units }\end{array}$ & UC & 28 & 0.17 & 1 \\
\hline Total & & 16,633 & 100 & \\
\hline
\end{tabular}

Note: 'FKR' is frontier knowledge requirement. Data come from form EIA-767, schedule III, section B, question 3(g). Data do not appear for 1998, 1999 and 2000. The response rate for the compliance strategy question in the survey was 91.9 per cent for all other years. Hyphen indicates unknown.

\footnotetext{
${ }^{8}$ For each ton of $\mathrm{SO} 2$ emissions an operator avoided through energy conservation measures, the EPA awarded an equivalent number of emission allowances.

${ }^{9}$ See definition in-text.
} 
Figure 2: Distribution of major US coal deposits, by coal rank

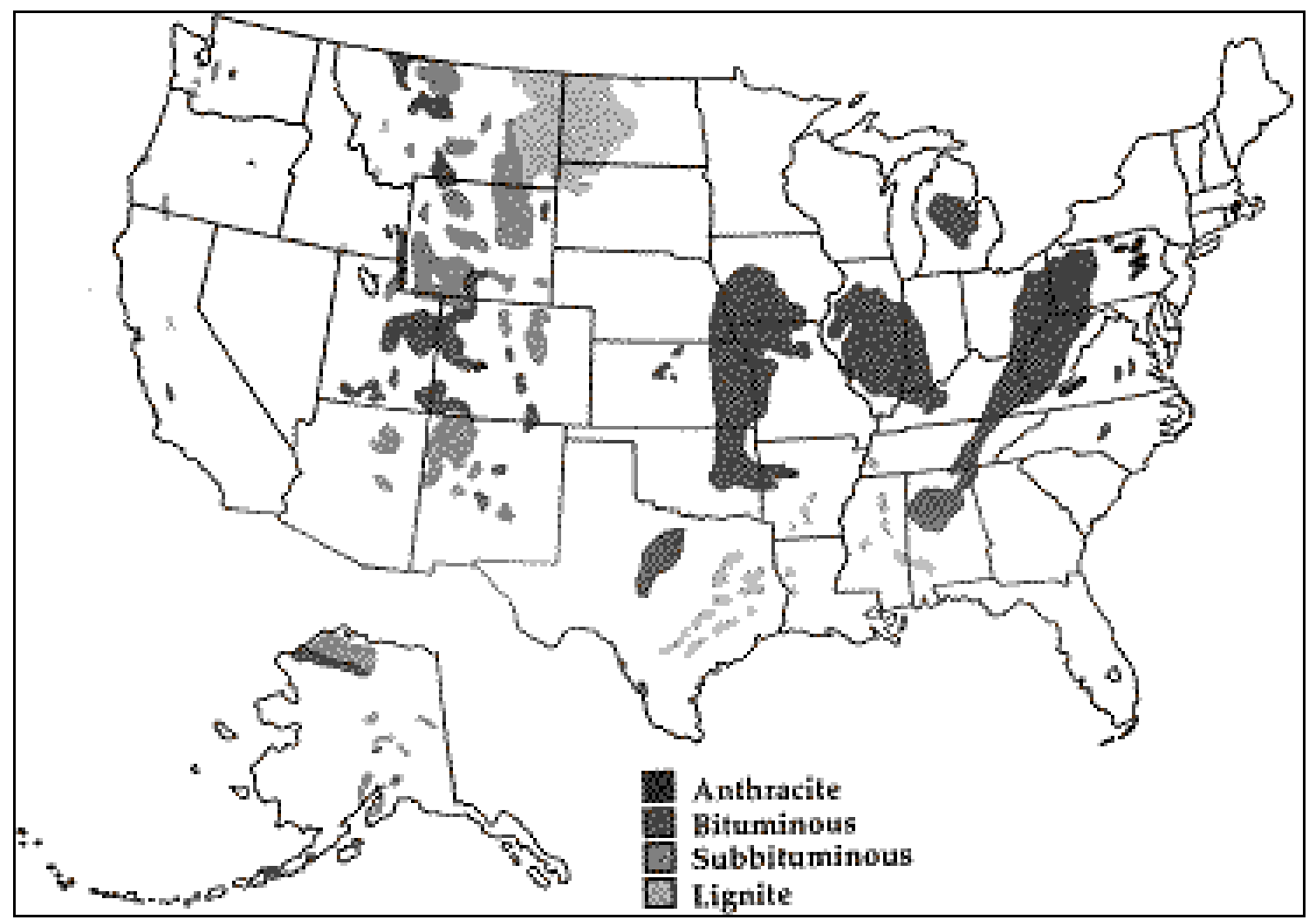

Source: American Coal Foundation (2005) 
Figure 3: Longwall shearer

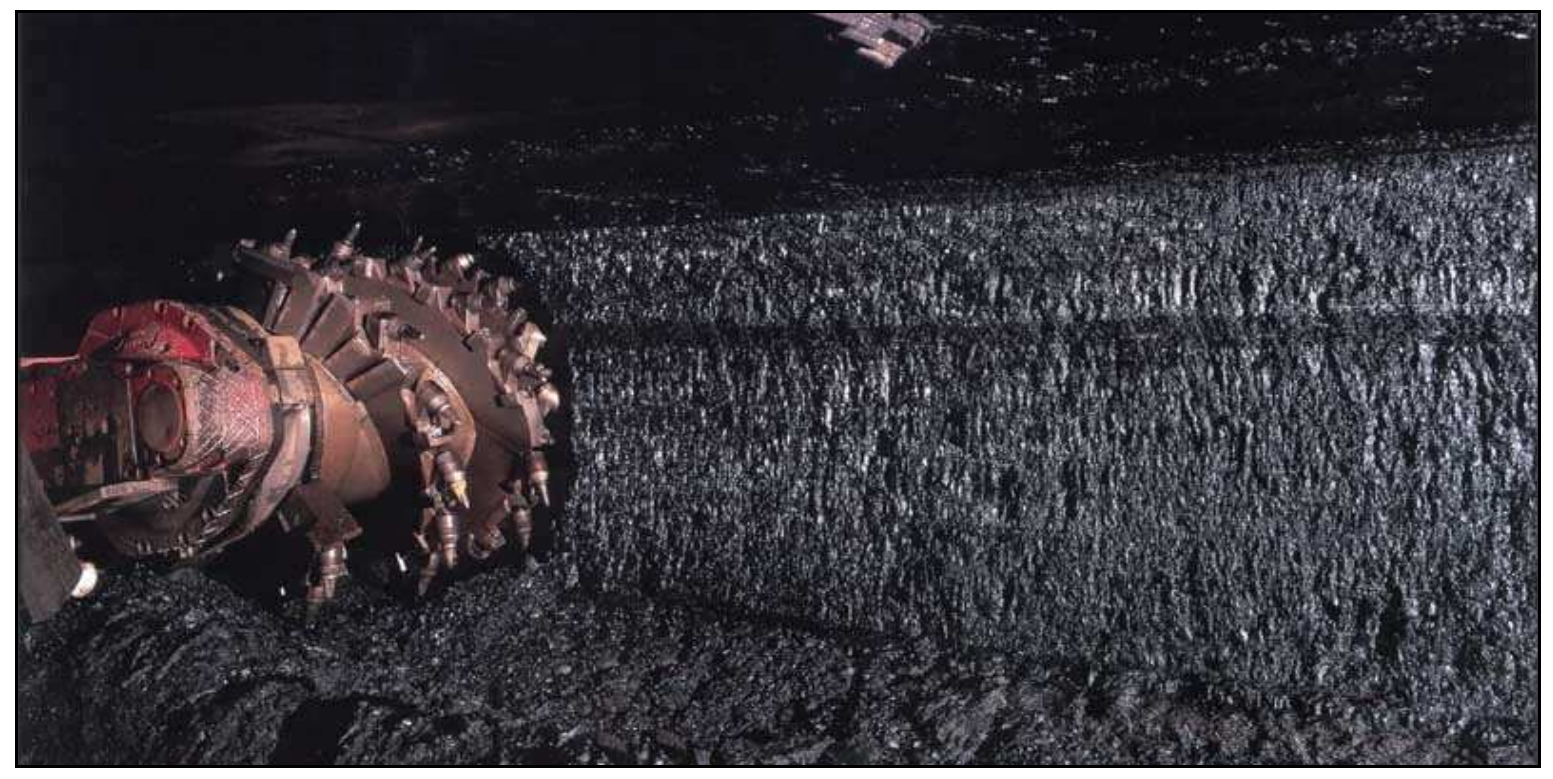

